\title{
The Role of City Design Elements in Tourist Villages as Interpreted by Online Media
}

\author{
Aurelia Silviana Theodora ${ }^{1}$, Pamela Felita Julyanto ${ }^{2 *}$, Adelia Tio Novita ${ }^{3}$, Larasati Putri \\ Kartika ${ }^{4}$, Agus Suharjono Ekomadyo ${ }^{5}$, Vanessa Susanto ${ }^{6}$. \\ 1,2,3,4,5,6Bandung Institute of Technology, Indonesia. \\ Corresponding Author: pamelaa.felita@gmail.com
}

\begin{tabular}{|c|c|}
\hline & Abstract \\
\hline $\begin{array}{l}\text { Keywords: } \\
\text { Online media; Penta } \\
\text { helix; Touristvillage; } \\
\text { urban design elements }\end{array}$ & $\begin{array}{l}\text { In recent years, there have been numerous slum settlements in } \\
\text { Indonesia that were transformed into tourist villages established by } \\
\text { creative movements with an artistic approach. As a prominent aspect } \\
\text { of the Penta helix, online media is considered a fundamental role in } \\
\text { publicizing creative campaigns. This research utilizes the content } \\
\text { analysis method to know how a designated space surfaces from a } \\
\text { creative movement - the urban design elements of a tourist village's } \\
\text { inauguration, visualized by the media. Analysis of three tourist } \\
\text { villages reveals two distinct patterns of tourist village coverage by the } \\
\text { media: attractive city design elements that encourage social activities } \\
\text { (Kampung Dago Pojok) and the unique form and massing as its } \\
\text { picturesque appeal (Kampung Warna-Warni \& Kampung Pelangi). } \\
\text { Observational data shows that the internet has influenced the } \\
\text { fabrication of tourist villages supported by creative movements with } \\
\text { various urban design approaches. }\end{array}$ \\
\hline $\begin{array}{l}\text { DOI: https://doi.org/ } \\
\text { @ } 2017 \text { The Authors. P }\end{array}$ & 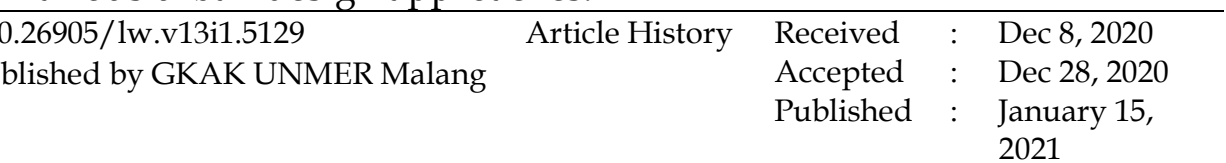 \\
\hline
\end{tabular}

\section{INTRODUCTION}

Over the last few years, creative campaigns paved the way for urban villages as a tourist destination. Urban villages itself is a high-density settlement that is inhabited informally. The urban village is the origin of Indonesia's distinctive settlement culture (Kusyala, 2008; Bawole, 2020). In this particular place, residents from various socioeconomic statuses can prevail amid the city's rapid development. There have been many community empowerment initiatives to improve the urban village environment (Lathif, 2020). Most of these initiatives are manifested in creative movements, thus transforming the urban village into a tourist village through an artistic approach. Urban villages should harvest their unique identity by exploring their potential via collective movements (Jabaril, 2017) since social interaction is an inherent culture that is the urban villages' soul (Tamariska \& Ekomadyo, 2018). An example of this campaign is to improve the built environment by creating spaces for community activities. The physical elements 
in urban design are involved in placemaking to adequately develop a tourist village with specific characteristics that can attract tourists (Susanti \& Ikaputra, 2020). The villages' existing potential should be optimized to have equal opportunities in their development and persistently shape tourism areas' patterns (Tania et al., 2018). Public perceptions of activities can shape spaces that might not be in place because personal, closed, and communal activities can occur in urban village street areas considered public (Putera, 2014). Interaction spaces are necessary for the urban village community could be fulfilled through the residents' ability to conceptualize space. The simple notion of interaction space can present a breakthrough to get the quality of interaction they want within limited land (Tamariska \& Ekomadyo, 2017).

In creative culture development, a mechanism is needed on how to make the program sustainable. Conceptually, the Penta helix synergy exhibits a suitable collaboration model in driving the creative economy. Local communities are encouraged to develop various kinds of innovations and synergies with Penta helix to develop existing potential (Yunas, 2019). What is meant by Pentahelix is the collaboration of five elements of tourism stakeholder: (A) Academics, (B) Business Sector, (C) Community, (G) Government, and (M) Media or commonly abbreviated as ABCGM. Penta helix itself is a mechanism that involves five stakeholders and explains their relationship into a particular mechanism (Sukarno et al., 2020). It also indicates the inclusion of the Penta helix approach in community empowerment (Muhammad et al., 2017). Each element plays a part that must complement and share the same vision in actualizing a synergistic program. As one of the stakeholders in Pentahelix, the media has a role as an expander whose job is to publish information and promote the brand image of a creative movement to the public.

Through extensive media coverage, creative campaigns can develop rapidly through publications to promote these destinations to the public. The broadcasting of such villages by the media will encourage the public to visit that particular village. By understanding how the media envision a space, we can consider its role in designing a creative movement, especially in urban villages' establishment. This research shows how urban design elements shape a tourist village based on the news on the internet. We hope that mapping the urban design elements' contribution to each tourist village can gain supplementary knowledge about the formation of tourist villages in Indonesia through the media perspective.

\section{LITERATURE STUDIES}

\section{Tourist Village}

Several aspects make a village a tourist destination, such as attractions, accessibility, and amenities, usually shortened to 3A (Yoeti, 1997). Attractions are all things that can attract tourists to visit tourist regions. Attractions can be differentiated into objects available in the universe or human-made creations - in this case, are history, culture, and religion. Accessibility is the infrastructure that facilitates tourists to access tourist destinations conveniently. Accessibility can be in transportation modes and services, including roads, bridges, terminals, stations, etc. Amenities are an aspect that supports the activities occurring at these tourist attractions. Amenities include restaurants, clean water, communications, entertainment, and security. 


\section{City Design Elements}

Hamid Shirvani (1985) explains that urban design is part of a planning process related to its physical conditions. It is necessary to pay attention to design elements within the urban planning environment, which will be the area's primary features. According to Shirvani, city design elements are divided into eight categories: land use, building mass and form, circulation and parking, open spaces, pedestrian areas, signage, supplementary activities, and conservation.

The first element is land use, a regulation regarding land design in a city related to the building's function. Land use classification is used to facilitate land use arrangement at a macro scale. The next element is the building mass and form, a zoning arrangement regulating the building's physical features, such as the height difference, setback, and building coverage. It also includes the size, intensity, scale, texture, color, etc. Circulation is the most crucial thing in planning. The third element is circulation and parking, emphasizing vehicle circulation. The availability of parking spaces also influences the environment, which will craft the area's visual imagery, while the fourth one is the open space, often defined as landscapes, parks, and recreational spaces in urban areas. Subsequently, the fifth element is the pedestrian area, a key element of users' comfort and a supporting urban city element, and the sixth one is signage, a direction to a particular area. Signage includes billboards, road signs, and other information signs. The penultimate element is supplementary activities, all the buildings' functions and activities that sustain public spaces' existence in the city. Finally, conservation is a conceptual element that considers single buildings, architectural structures, styles, usability, age, or building-worthiness.

\section{METHODS}

This research utilizes the qualitative method. Qualitative research is a descriptive study because it seeks to articulate data with words or sentences divided into categories to obtain conclusions (Arikunto, 2009). The next method used is the content analysis method. Content analysis is a method for collecting and analyzing the content of a "text," where the text is interpreted in quantifiable analysis units (Ekomadyo, 2006). Fraenkel and Wallen (2007: 483) state that content analysis is a technique that researchers can use to observe human behavior indirectly through an analysis of their communication platforms, such as textbooks, essays, newspapers, novels, magazine articles, songs, advertising images, and all types of interaction that can be analyzed.

The analysis was carried out on three tourism villages selected as research objects: Kampung Wisata Dago Pojok, Kampung Warna-Warni, and Kampung Pelangi. These villages were selected based on their similarities as tourism villages that are thematic urban villages from different provinces in Java: West Java, East Java, and Central Java. The data were taken through various online news portals and analyzed in 2 stages. The first stage uses descriptive analysis to map 30 online news to see each tourist village's trends every year. From 30 news items, it is filtered down into 20 items to be analyzed in the second stage. This filtering is applied to sort news data relevant to the analysis to be carried out. The next stage analysis utilizes the content analysis method to extract words according to the theoretical framework used - forming a tourist village 3A by Yoeti (1997) and elements of urban design by Shirvani (1985). This analysis aims to determine which urban design elements are most dominant in establishing a tourist village. 
LOCAL WISDOM, Vol. 13 No. 1 January 2021

Local Wisdom Scientific Online Journal

\section{RESULTS AND DISCUSSION}

\section{Study Cases}

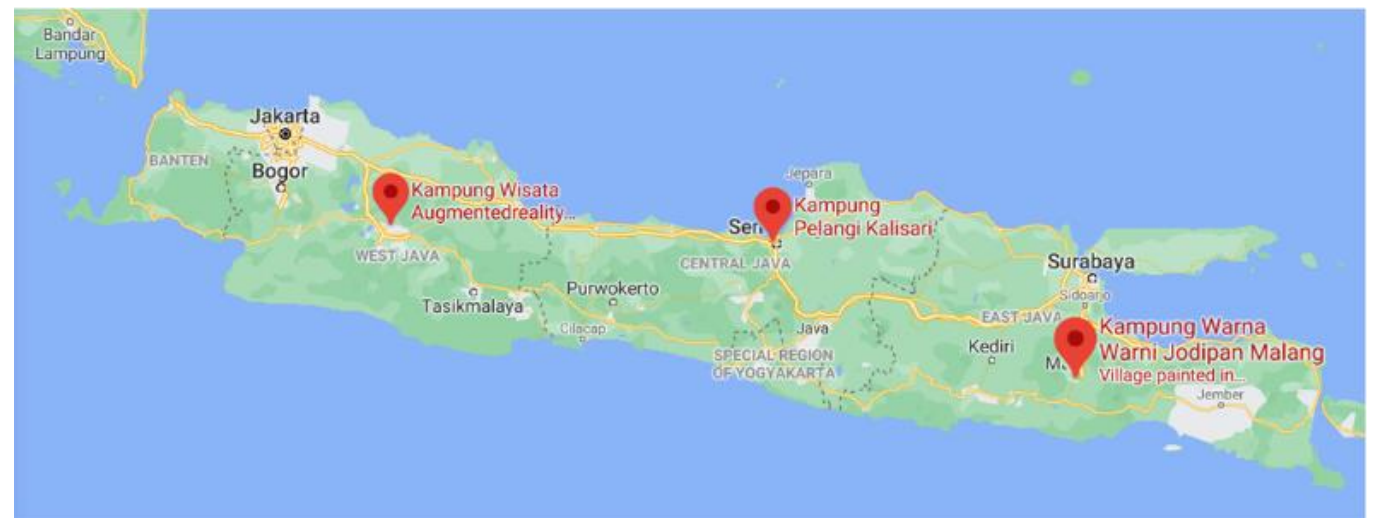

Figure 1. The Location of the Three Villages on Java Island, Indonesia

(Source: google.maps.com)

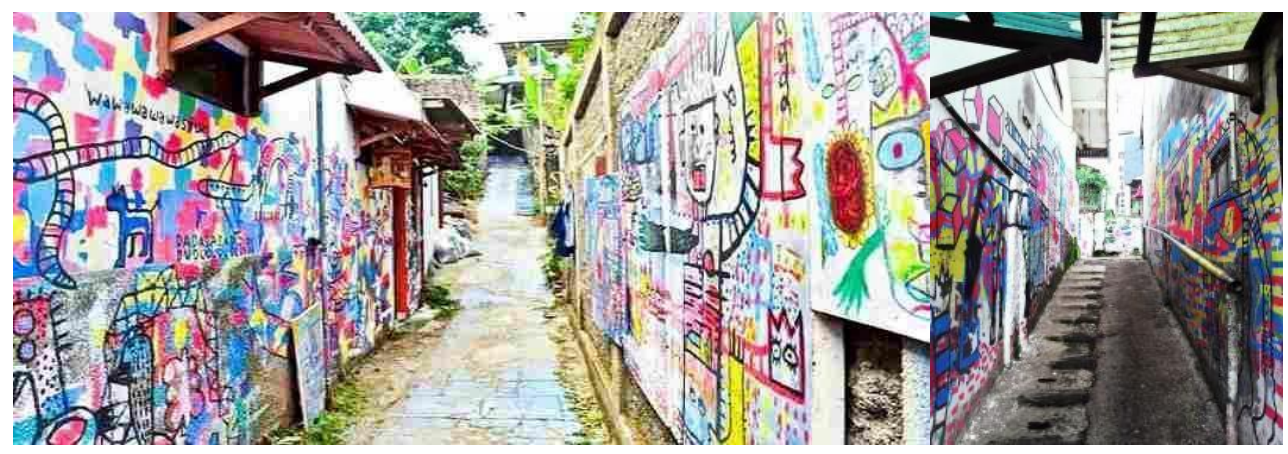

Figure 2. Murals in Kampung Dago Pojok Alleys.

(Source: tempatwisatadibandung.info)

The first village studied is Kampung Dago Pojok. This village is a tourist village located in Jl. Dago Pojok No.95, Dago, Coblong District, Bandung City, West Java. It used to be an ordinary village located in the middle of the city that was later transformed into a tourist village thanks to a local artist called Rahmat Jabaril, the pioneer and creator of Kampung Dago Pojok. He transformed the village's alleys and roads into pleasant places and invoked the residents' creativity (Ekomadyo et al., 2020). This evolutionary move makes Dago Pojok an art and cultural tourism destination in Bandung that has been recognized and protected by the government. This community uses its local knowledge as a cultural reference to produce space creatively within its artistic competence (Figure 1), used as a node to build social networks with other actors. (Ekomadyo \& Riyadi, 2020). Since then, the idea of designating Kampung Dago Pojok as an essential part of Bandung's tourism economy has progressed rapidly. These ideas are focused on turning this village into a tourist destination with various attractions to generate local economic activities carried out by residents (Ekomadyo et al., 2013). 


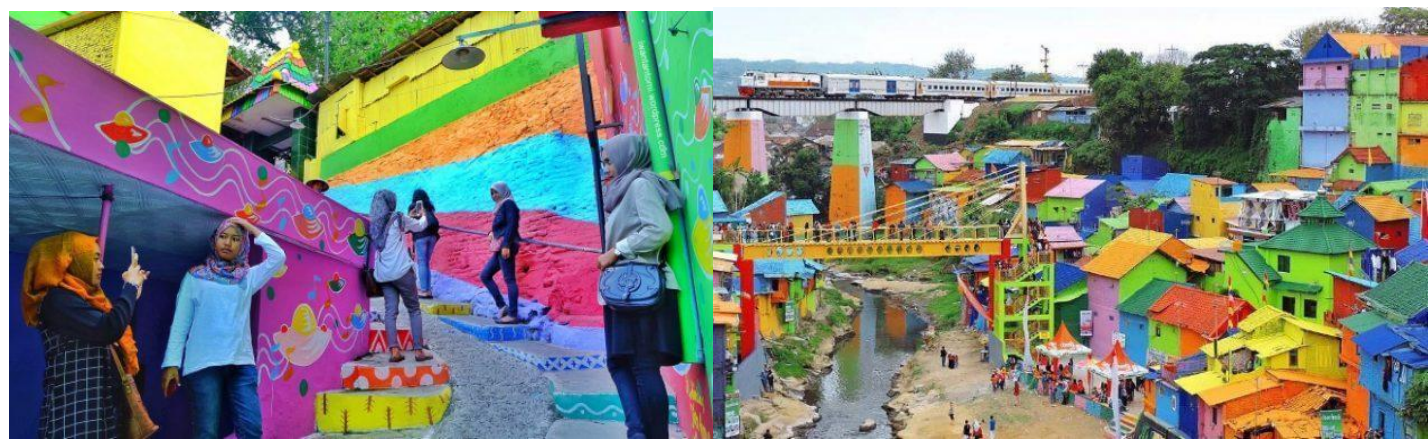

Figure 3. (Left) Photo spots around Kampung Warna-Warni Jodipan. (Right) Kampung WarnaWarni Jodipan. (Source: bosniatravel.net)

The second village is Kampung Warna-Warni. Kampung Warna-Warni is an urban village altered into a tourist village, located in Gang 1, Jodipan Village, Blimbing District, Malang City, East Java. This village used to be a slum before several students from the Communication Department of the University of Muhammadiyah Malang (UMM) took the initiative to turn this village into an attractive one. This village is painted in vivid colors and entices tourists to visit it as it becomes one of Malang's tourist attractions. This program has successfully eliminated the residents' bad habits since the village is now converted to a prime tourist location. The presence of visitors proves beneficial for the community as it motivates them to prioritize comfort towards the flocking tourists (Wulandari, 2017). The tourists' enthusiasm prompted them to increase the village's visual appeal, as shown from several photo spots, picturesque walls, umbrella aisles, and other facilities such as food stalls, public toilets, parking lot, etc. (Nur et al., 2019). On-site observations showed that visitors are interested in coming to Kampung Warna-Warni Jodipan because they have seen many photos of this village uploaded on Instagram (Rizki \& Pangestuti, 2017).

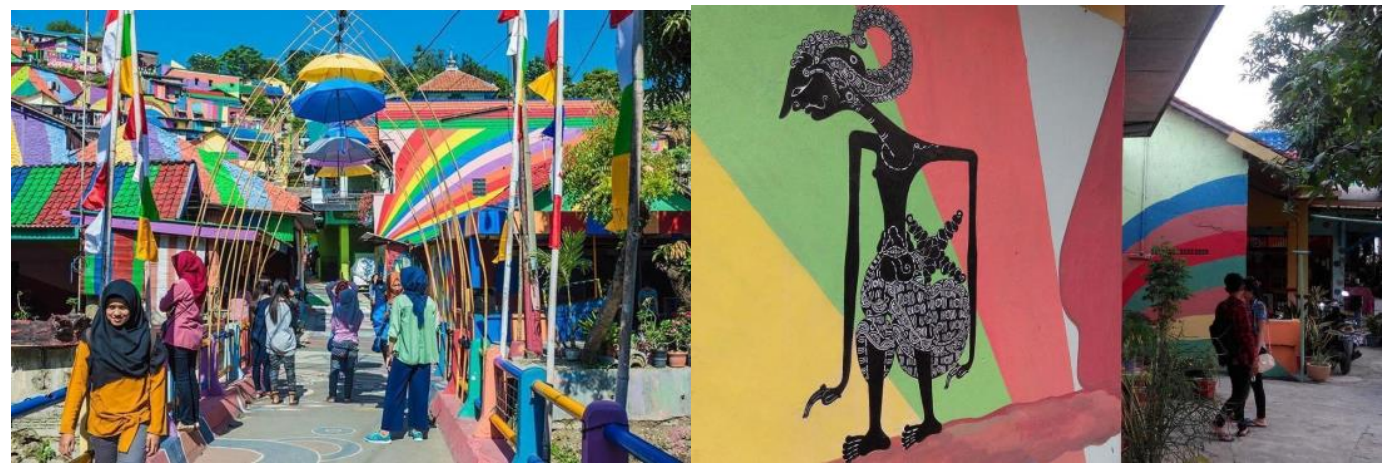

Figure 4. (Left) Bridge in Kampung Pelangi. (Right) Mural in Kampung Pelangi.

(Source: tutyqueen.com)

Lastly, the third village is Kampung Pelangi, a tourist village located in Jl. Dr. Sutomo, Randusari Village, South Semarang, Central Java. Kampung Pelangi is renowned for its vibrant-colored houses, thus earning them their name (Rainbow Village). It all began from a flower market's renovation near Kalisari. This village serves as the backdrop for the now clean and tidy flower market, but at that point, the village was still a slum. Therefore, Semarang's mayor took the initiative to remodel the village by painting it with colors akin to the rainbow. This village then became a trendsetter in transforming 
a village's appearance, which inspired other Semarang villages (Saraswati \& Kiswari, 2017). After it became a tourist attraction, many developments took place in Kampung Pelangi, such as advancing the local economy by opening resident-owned stalls, providing photo spots for visitors, and building supporting facilities: food courts, guardhouses, and parks parking lots, and others (Febriandini, 2019). Sustainable tourism is expected to be implemented in Kampung Pelangi Semarang, where tourism development and investment should not carry a destructive impact and integrate with the existing environment for an extended period (Wuryaningsih et al., 2018). Apart from that, Kampung Pelangi has its unique native content: historical sites surround kampung Pelangi, and its location was once part of Semarang's historical account, including fascinating urban legends or local myths. This phenomenon is a cumulation of local content intertwined in a narrative that forms the community's identity (Irwandi et al., 2019).

\subsection{TOURIST VILLAGES COVERAGE}

The data was collected by searching for 30 news items on each tourism village from various online media portals, news media, and travel media. The News media covers Kompasiana, CNN Indonesia, Liputan 6, Jawa Pos, Detik, Tribunnews, Jabar Express, and others, while the travel media are Wisata Bandung, Serba Bandung, Jejak Piknik, Travelling Yuk, etc. The number of mass media news and the year of publication can be seen in Diagram 1.

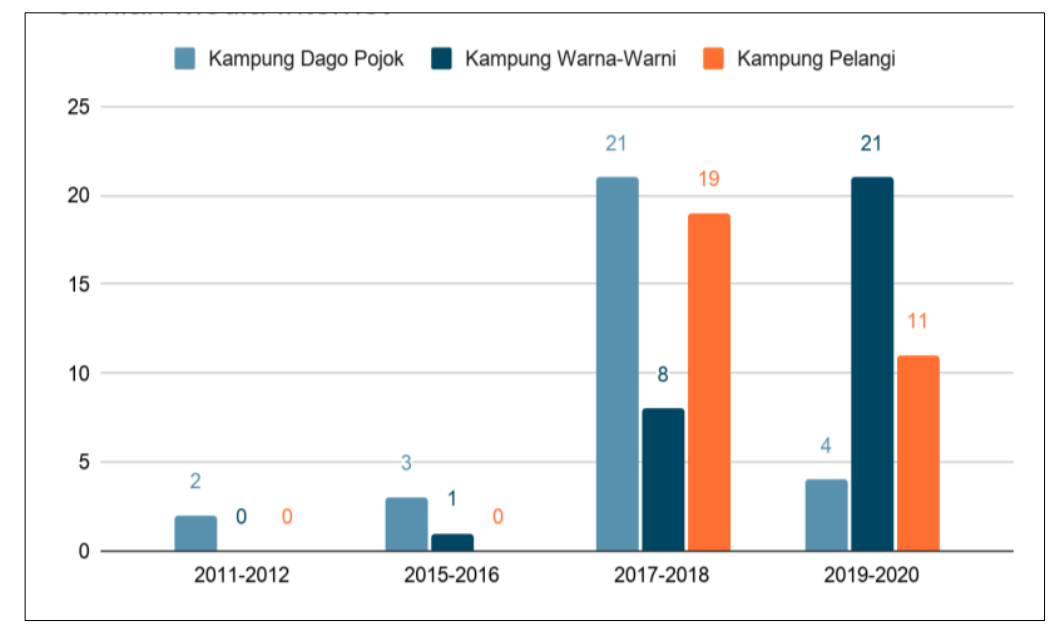

Diagram 1. News Coverage on Villages per Year

(Source: Author's Analysis, 2020)

Based on Diagram 1, it can be concluded that Kampung Dago Pojok's existence, as reported by online media, was the highest in 2017-2018. However, their coverage can be traced back to 2011, which indicates that the village has been a tourism village earlier on. Meanwhile, Kampung Warna-Warni and Kampung Pelangi were only noticed by online media in 2017 because these two villages were just inaugurated that year. However, Kampung Warna-Warni's coverage has increased significantly in 2019-2020 on the internet because of its progressive developments. 


\section{Analysis of Tourist Villages Coverage}

The analysis was carried out on each of the sorted 20 news items from every village where it includes evaluating three main aspects of a tourist village's primary support: attractions, accessibility, and amenities. The results can be seen in Diagram 2 .

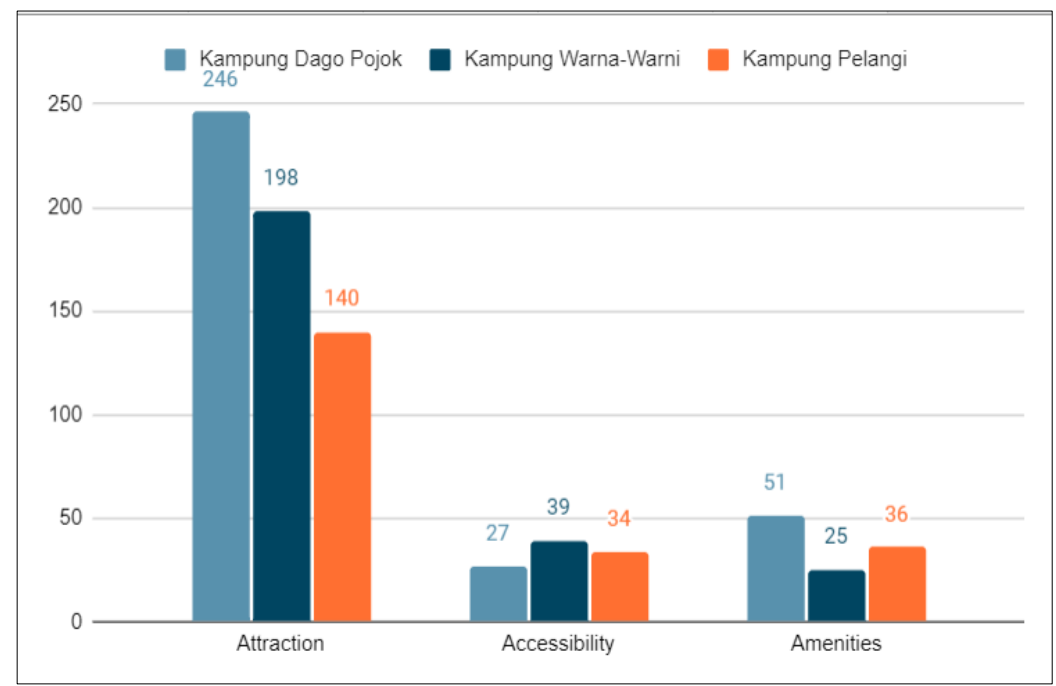

Diagram 2. Aspects of Tourist Village Formation

(Source: Author's Analysis, 2020)

In Kampung Dago Pojok, the reported attractions include mural art, batik art, Sundanese music, festivals, performing arts, culinary, handicraft products, etc. Its attraction is eminently dominated by matters regarding culture and arts, especially Sundanese art. Meanwhile, the exciting combination of houses painted in colors, murals, selfie spots, vibrant pedestrian alleys, and a glass bridge over the river are the ones noticed in Kampung Warna-Warni. In Kampung Pelangi, the coverage is comparable to the former with the additional colorful bridges and stairs. Every report discusses each village's accessibility - access to the location, reachability, public transportation, etc. These news reports also explain their amenities supporting the tourist activities: street vendors, mini-libraries, souvenir shops, food courts, or accommodation.

The analysis found that there is a tendency to reporting the villages' attraction aspect by online media. Out of the selected 20 news items from each village, Kampung Dago Pojok's attraction was covered 246 times, while Kampung Warna-Warni and Kampung Pelangi each stood at 198 times and 140 times, respectively. This aspect is the most dominant primarily because the media tends to report things that can straightaway captivate readers' attention, and understandably, the attraction stands out the most of all three.

\section{Analysis of Urban Design Elements Coverage}

The next stage of the analysis is data review based on Shirvani's city design theory, which consists of 8 main elements: land use, building mass and form, circulation and parking, open spaces, pedestrian areas, signage, supplementary activities, and conservation. After being categorized based on the 3A tourism aspect, the existing data is sorted into eight urban design elements. This stage's results can be seen in Diagram 3. 
LOCAL WISDOM, Vol. 13 No. 1 January 2021

Local Wisdom Scientific Online Journal

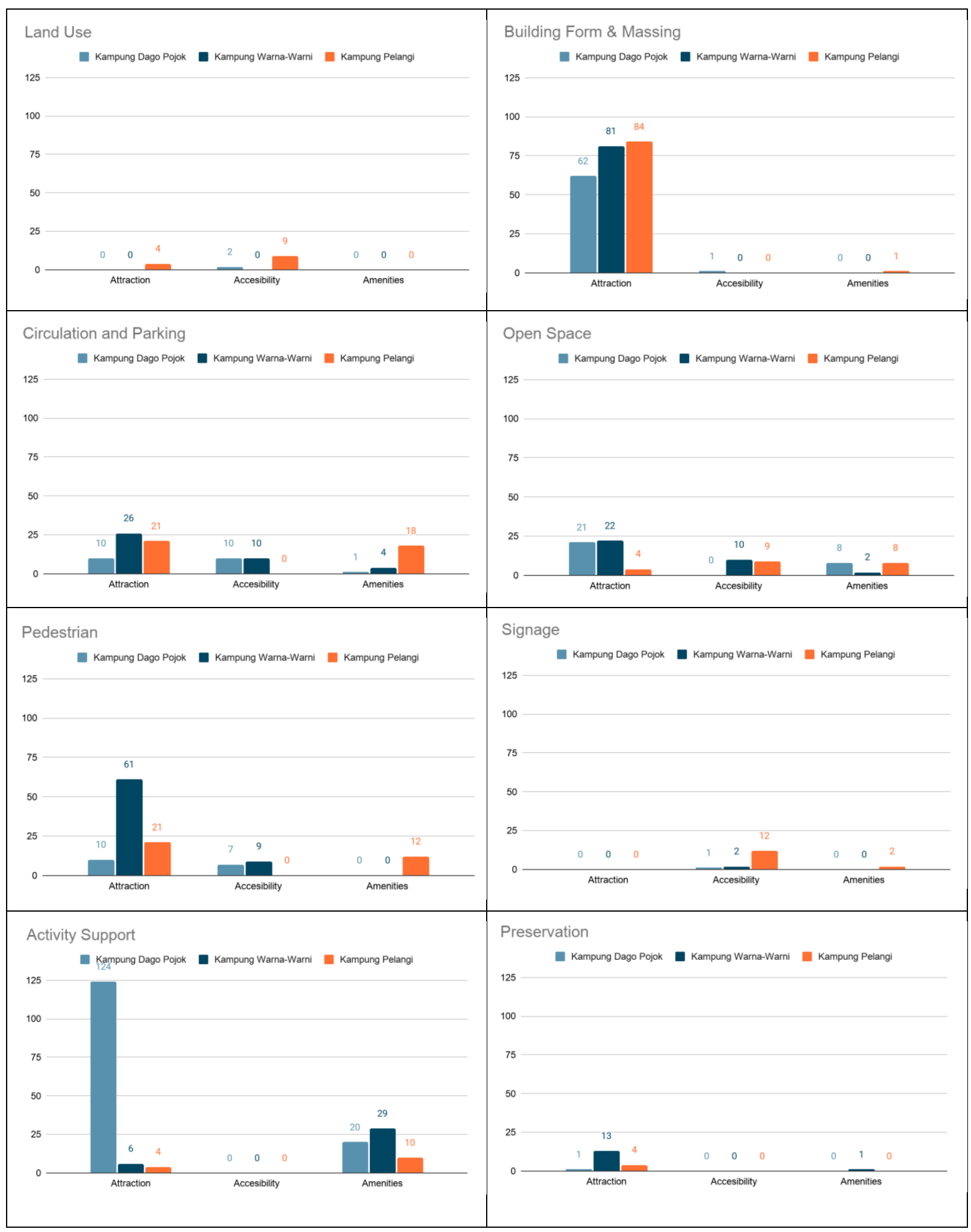

Diagram 3. Analysis of Coverage of Tourist Villages' Urban Design Elements

(Source: Author's Analysis, 2020)

Based on previous data, it was discovered that attraction is the paramount aspect of a tourism village reported by online media. However, a further assessment determined from urban design theory revealed two different patterns from this aspect alone. For 
Kampung Dago Pojok, the supplementary activities contribute the greatest to its attractiveness, while Kampung Warna-Warni and Kampung Pelangi utilize their unique building mass and form to entice visitors.

In Kampung Dago Pojok, the supporting elements are visibly dominant; therefore, the media widely reports their activities that support public space formation. Activities described consist of artistic interests from painting, dance, martial arts, music to crafts. In this case, it can be concluded that the village takes an approach with supplementary activities in the form of arts and culture as a crucial element in designing and maintaining a tourist village. Whereas in Kampung Warna-Warni and Kampung Pelangi, the building mass and form is preeminent that the media continuously talked about the village's physical environment: the explosion of colors on the village walls. Apart from the walls, other infrastructures such as bridges and murals also invoke fascination.

\section{CONCLUSION}

The urban village displays its alluring charm in the hustle and bustle of urban life. Several urban villages, which are typically slums, have been transformed into tourist villages with their distinct identities. The urban villages' popularity is also a direct result of the media's contribution. This study provides an overview of how the internet reports urban design elements in tourist villages. In the Penta helix concept, the media acts as a contributor whose job is to carry out publications to broadcast information on creative movements to the public regarding tourist villages. The online media coverage aims to promote the tourist villages and determine the most compelling urban design elements in each village. This notion undoubtedly demonstrates how the media play a vital role in visualizing the formation of urban villages.

Based on the analysis, the media is more interested in reporting the tourist area's attractions feature than the others since it draws more attention from their readers' regarding a prospective tourist destination. While reporting their urban design elements, the media has two patterns of inclination in covering a tourist village's creative campaign, reporting on attractions in a visual context through the design of the building mass and form. The other relies on the supplementary activities that figure the public spaces around the village. This evidence shows that establishing a tourist village backed by creative movements can be carried out with various urban design elements.

\section{REFERENCES}

Bawole, P. 2020. Urban village development as an alternative destination for special interest tourism. [Pengembangan kampung kota sebagai salah satu alternatif tujuan wisata minat khusus]. Arteks : Jurnal Teknik Arsitektur, Volume 5 Issue 1. pISSN 2541-0598; eISSN 2541-1217

Ekomadyo, A.S. 2006. Prospects for the Application of Content Analysis Methods in Media Research. [ Prospek Penerapan Metode Analisis Isi (Content Analysis) Dalam Penelitian Media Arsitektur]. Jurnal Itenas 2(10): 51-57

Ekomadyo, A.S., Prasetyo F.A., \& Yuliar, S. 2013. Place Construction and Urban Social Transformation: An Actor Network Theory Analysis for Creative-Kampung 
Phenomena In Bandung. HABITechno: InnovationHousing and Settlement Technology: 230-239

Ekomadyo, A.S., and Riyadi, A. 2020. Design in Socio-technical Perspective: An ActorNetwork Theory Reflection on Community Project 'Kampung Kreatif' in Bandung, Archives of Design Research 33(2): 19-37, (Q1, 0,2), doi: https://doi.org/10.15187/ adr.2020.05.33.2.19

Ekomadyo, A.S., Martokusumo, W., et al. 2020. Field of Creative-Cities Movement and Cultural Sustainability: Learning from Place-Making in Kampung Kreatif Dago Pojok and Kopi Pasar Los Tjihapit in Bandung. Advances in Science and Technology 103:11-17

Febriandini, A.P. dkk. 2019. The Role of Stakeholders in Empowerment in Kampung Pelangi. [Peran Stakeholder Dalam Pemberdayaan Di Kampung Pelangi]. Jurnal Ilmiah Tata Sejuta STIA Mataram 5(1):90-104

Fraenkel, J. R., and Wallen, N.E., 2007. How to Design and Evaluate Research in Education. Boston: McGraw-Hill Higher Education.

Irwandi E., Sabana S., et al. 2019. Seeing Local Wisdom as Form of Visual Art for Creating Place Identity in Kampung Pelangi, Semarang. Advances in Social Science, Education and Humanities Research 444: 271-275

Kusyala, D. (2008). The Principle of Urban Village Development based on the Population Pattern of the People. [Prinsip Pengembangan Kampung Kota berdasarkan Pola Berhuni Warga]. Master Thesis. Architecture ITB.

Lathif, A.S. 2020. Living in Alleys: A Story of Kampung Kota: Springer Nature Switzerland

Muhammad, A., Muhammad E., et al. 2017. Penta Helix Model: A Sustainable Development Solution Through the Industrial Sector. HISAS Human and Social Science Journal ISSN: 2597-8640. Putera, Y A. (2014) Ambiguitas Ruang Kampung Pluis dalam Perspektif Privat-Publik. E-Journal Graduate Unpar 1(2), Universitas Kristen Parahyangan.

Nur, R., Sudikno, A., dkk. 2019. Activities and Synomorphy in Public Spaces of the Colorful Village of Jodipan, Malang City. [Aktivitas Dan Synomorphy Pada Ruang Publik Kampung Warna-Warni Jodipan Kota Malang]. Pawon Jurnal Arsitektur 3(1):57-68Rizki M.A., \& Pangestuti E. 2017. Pengaruh Terpaan Media Sosial Instagram Terhadap Citra Destinasi Dan Dampaknya Pada Keputusan Berkunjung (Survei pada Pengunjung Kampung Warna Warni Jodipan, Kota Malang). Jurnal Administrasi Bisnis 49(2): 157-164

Saraswati R.D., \& Kiswari M.D.N. 2017. Environmental Aesthetic Study of Kampung Pelangi, Case Study: Jalan Lingkungan Kampung Pelangi Gg. VI. [Kajian Estetika Lingkungan Kampung Pelangi, Studi Kasus: Jalan Lingkungan Kampung Pelangi Gg. VI]. Prosiding Seminar Nasional Arsitektur Populis: B59-66 
The Role of City Design Elements in Tourist Villages as Interpreted by Online Media Aurelia Silviana Theodora, Pamela Felita Julyanto, Adelia Tio Novita, Larasati Putri Kartika, Agus Suharjono Ekomadyo, Vanessa Susanto.

Shirvani, H.. 1985. The Urban Design Process. New York : Van Nostrand Reinhold.

Sukarno G, Rasyidah R., et al. 2020. Improve Creative Industry Competitiveness Penta Helix and Human Capital in Digital Era. Advances in Social Science, Education and Humanities Research: 423

Susanti, A.D. \& Ikaputra. 2020. Urban Morphology of Urban Village Artifacts. [Morfologi Urban Artefak Kampung Kota]. MARKA (Media Arsitektur dan Kota) Jurnal Ilmiah Penelitian 4(1):17-26

Tamariska S.R., Ekomadyo A.S. 2017. 'Place-Making' Urban Village Social Interaction Room, Case Study: Corridor of Jalan Tubagus Ismail Bawah, Bandung. ['PlaceMaking' Ruang Interaksi Sosial Kampung Kota, Studi Kasus: Koridor Jalan Tubagus Ismail Bawah, Bandung]. Jurnal Koridor 8(2): 172-183

Tamariska S.R., \& Ekomadyo A.S. 2018. 'Society Bond' In City Kampong, Bandung: Study Of Communal Space Value Representation In Urban Kampong Space. International Seminar HABITechno.

Tania, D.J., Ekomadyo, A.S., dan Zulkaidi, D. 2018. Transformation of a Tourist Village into a Tourism Village. Case study: Prawirotaman Yogyakarta. [Transformasi Kampung Turis menjadi Kampung Wisata. Studi kasus: Prawirotaman Yogyakarta]. Prosiding Seminar Kota Layak Huni. Universitas Trisakti Jakarta, 22 Feb 2018

Wisesa, K.A., dkk. 2018, Creativity Based Tourism in Kampung Kreatif Dago Pojok Bandung. Journal of Tourism Destination and Attraction 6(1):15-24

Wuryaningsih T.I., Setioko B., et al. 2018. Visual Quality Effect on Sustainability of Kampung Pelangi Semarang. Jurnal Teknik Sipil \& Perencanaan 20(2): 98-106 
Appendix: List of Online Media Coverage Analysed

\begin{tabular}{|c|c|c|c|c|}
\hline \multicolumn{5}{|c|}{ Kampung Dago Pojok } \\
\hline No. & Title & Link & Publisher & $\begin{array}{l}\text { Publish } \\
\text { Date }\end{array}$ \\
\hline 1 & $\begin{array}{c}\text { Mengulik Keunikan Kampung } \\
\text { Dago Pojok }\end{array}$ & $\begin{array}{l}\text { http://www.koran- } \\
\text { jakarta.com/mengulik-keunikan- } \\
\text { kampung-dago-pojok/ }\end{array}$ & Koran Jakarta & $\begin{array}{l}10 \\
\text { Agustus } \\
2018\end{array}$ \\
\hline 2 & $\begin{array}{l}\text { Rahmat Jabaril, Mengubah } \\
\text { Kampung Kumuh Menjadi } \\
\text { Kawasan Wisata }\end{array}$ & $\begin{array}{c}\text { https://www.kompasiana.com/ma } \\
\text { riahardayanto/59e064fa147f9612457 } \\
\text { 49ab2/rahmat-jabaril-sang- } \\
\text { pendobrak?page=all }\end{array}$ & Kompasiana & $\begin{array}{c}13 \\
\text { Oktober } \\
2017\end{array}$ \\
\hline 3 & $\begin{array}{c}\text { Menembus Batas Kreatifitas di } \\
\text { Dago Pojok }\end{array}$ & $\begin{array}{c}\text { https://www.medcom.id/rona/wi } \\
\text { sata-kuliner/5b2MdVeN- } \\
\text { menembus-batas-kreatifitas-di- } \\
\text { dago-pojok }\end{array}$ & Medcom.id & $\begin{array}{l}29 \text { Juli } \\
2016\end{array}$ \\
\hline 4 & $\begin{array}{l}\text { Wilujeng Sumping di Desa Dago } \\
\text { Pojok Sabandungeun }\end{array}$ & $\begin{array}{c}\text { https://desadagopojok.wordpress. } \\
\text { com/ }\end{array}$ & - & 2018 \\
\hline 5 & $\begin{array}{c}\text { Kampung Wisata Dago Pojok, } \\
\text { Wisata Berbasis Kreativitas }\end{array}$ & $\begin{array}{c}\text { https:// keluyuran.com/kampung- } \\
\text { wisata-dago-pojok/ }\end{array}$ & - & $\begin{array}{l}15 \\
\text { Agustus } \\
2020\end{array}$ \\
\hline 6 & $\begin{array}{c}\text { Kota Bandung Getol Bangun } \\
\text { Kampung Wisata }\end{array}$ & $\begin{array}{l}\text { https://www.cnnindonesia.com/g } \\
\text { aya-hidup/20170929112312-307- } \\
\text { 244857/kota-bandung-getol- } \\
\text { bangun-kampung-wisata }\end{array}$ & $\begin{array}{c}\mathrm{CNN} \\
\text { Indonesia }\end{array}$ & $\begin{array}{c}18 \\
\text { September } \\
2017\end{array}$ \\
\hline 7 & $\begin{array}{l}\text { Asyik, Bandung Bakal Punya } \\
\text { Kampung WIsata }\end{array}$ & $\begin{array}{c}\text { https:// biz.kompas.com/read/201 } \\
\text { 1/09/20/20442563/asyik.bandung. } \\
\text { bakal.punya.kampung.wisata }\end{array}$ & Kompas & $\begin{array}{c}20 \\
\text { September } \\
2011\end{array}$ \\
\hline 8 & $\begin{array}{c}\text { Kampung Dago Pojok Wisata Baru } \\
\text { di Kota Bandung }\end{array}$ & $\begin{array}{c}\text { https://news.detik.com/berita- } \\
\text { jawa-barat/d-1726645/kampung- } \\
\text { dago-pojok-wisata-baru-di-kota- } \\
\text { bandung }\end{array}$ & Detik news & $\begin{array}{c}20 \\
\text { September } \\
2011\end{array}$ \\
\hline 9 & $\begin{array}{c}\text { Menyapa Karya Nan Setia Dari } \\
\text { Labirin Kota }\end{array}$ & $\begin{array}{c}\text { https:// muda.kompas.id/baca/201 } \\
\text { 6/09/07/menyapa-karya-nan-setia- } \\
\text { dari-labirin-kota/ }\end{array}$ & Muda Kompas & $\begin{array}{c}7 \\
\text { September } \\
2016\end{array}$ \\
\hline 10 & Kampung kreatif dago pojok & $\begin{array}{c}\text { https://www.jawapos.com/tag/ka } \\
\text { mpung-kreatif-dago-pojok/ }\end{array}$ & Jawa Pos & $\begin{array}{c}2 \text { Februari } \\
2017\end{array}$ \\
\hline 11 & Oded Puji Kampung Dago Pojok & $\begin{array}{c}\text { https://jabarekspres.com/2017/od } \\
\text { ed-puji-kampung-dago-pojok/ }\end{array}$ & Jabar ekspres & $\begin{array}{c}13 \\
\text { Oktober } \\
2017\end{array}$ \\
\hline 12 & $\begin{array}{c}\text { Kampung Kreatif di Dago Pojok } \\
\text { Bandung }\end{array}$ & $\begin{array}{l}\text { https://ayobandung.com/read/20 } \\
\text { 19/06/24/55908/kampung-kreatif- }\end{array}$ & Ayobandung & $\begin{array}{l}22 \text { Juni } \\
2019\end{array}$ \\
\hline
\end{tabular}


The Role of City Design Elements in Tourist Villages as Interpreted by Online Media

Aurelia Silviana Theodora, Pamela Felita Julyanto, Adelia Tio Novita, Larasati Putri Kartika, Agus

Suharjono Ekomadyo, Vanessa Susanto.

\begin{tabular}{|c|c|c|c|c|}
\hline & & di-dago-pojok-bandung & & \\
\hline 13 & $\begin{array}{l}\text { Kampung Dago Pojok, Satu Lagi } \\
\text { Bukti Kreativitas Bandung }\end{array}$ & $\begin{array}{c}\text { https://travelingyuk.com/kampun } \\
\text { g-dago-pojok-bandung/108849/ }\end{array}$ & travelingyuk & $\begin{array}{l}23 \text { Juni } \\
2018\end{array}$ \\
\hline 14 & $\begin{array}{l}\text { Kampung Wisata Kreatif Dago } \\
\text { Pojok - Info Sejarah \& Alamat }\end{array}$ & $\begin{array}{c}\text { https://tempatwisatadibandung.inf } \\
\text { o/kampung-wisata-kreatif-dago- } \\
\text { pojok-bandung/ }\end{array}$ & $\begin{array}{l}\text { Tempat wisata } \\
\text { Bandung Info }\end{array}$ & $\begin{array}{c}24 \\
\text { September } \\
2017\end{array}$ \\
\hline 15 & $\begin{array}{c}\text { Kampung Wisata Kreatif Dago } \\
\text { Pojok: Destinasi Wisata Seni Sunda } \\
\text { di Tengah Kota }\end{array}$ & $\begin{array}{c}\text { https://www.infobdg.com/v2/ka } \\
\text { mpung-wisata-kreatif-dago-pojok- } \\
\text { destinasi-wisata-seni-sunda-di- } \\
\text { tengah-kota/ }\end{array}$ & Info Bdg.com & $\begin{array}{l}19 \text { Juni } \\
2015\end{array}$ \\
\hline 16 & $\begin{array}{c}\text { Desa Wisata Augmented Reality Di } \\
\text { Dago; Desa Wisata Tercanggih! }\end{array}$ & $\begin{array}{c}\text { https://www.bobobox.co.id/blog/ } \\
\text { desa-wisata-di-dago/ }\end{array}$ & bobobox & 2018 \\
\hline 17 & $\begin{array}{c}\text { Berwisata ke Kampung Kreatif } \\
\text { Dago Pojok }\end{array}$ & $\begin{array}{c}\text { https://yourbandung.com/berwisa } \\
\text { ta-ke-kampung-kreatif-dago-pojok- } \\
\text { bandung/ }\end{array}$ & Your Bandung & $\begin{array}{l}12 \\
\text { Oktober } \\
2017\end{array}$ \\
\hline 18 & $\begin{array}{l}\text { Kampung Wisata Kreatif Dago } \\
\text { Pojok Berdayakan Potensi Warga }\end{array}$ & $\begin{array}{c}\text { https://www.wisatabdg.com/2017 } \\
/ 10 / \text { kampung-wisata-kreatif-dago- } \\
\text { pojok.html }\end{array}$ & $\begin{array}{c}\text { wisatabdg.co } \\
\mathrm{m}\end{array}$ & $\begin{array}{l}08 \\
\text { Oktober } \\
2017\end{array}$ \\
\hline 19 & $\begin{array}{l}\text { Oded Dorong Pengembangan } \\
\text { Kampung Wisata Dago Pojok }\end{array}$ & $\begin{array}{c}\text { https:// bandung.bisnis.com/read/ } \\
\text { 20180806/549/1113411/oded- } \\
\text { dorong-pengembangan-kampung- } \\
\text { wisata-dago-pojok }\end{array}$ & $\begin{array}{l}\text { bandung.bisni } \\
\text { s.com }\end{array}$ & $\begin{array}{l}06 \\
\text { Agustus } \\
2018\end{array}$ \\
\hline 20 & $\begin{array}{c}\text { Kampung Kreatif Dago Pojok } \\
\text { Tawarkan Wisata Budaya Buat } \\
\text { Wisatawan }\end{array}$ & $\begin{array}{c}\text { https://www.serbabandung.com/ } \\
\text { kampung-kreatif-dago-pojok/ }\end{array}$ & $\begin{array}{l}\text { serbabandung. } \\
\text { com }\end{array}$ & $\begin{array}{c}24 \\
\text { Februari } \\
2018\end{array}$ \\
\hline
\end{tabular}

\begin{tabular}{|c|c|c|c|c|}
\hline \multicolumn{5}{|c|}{ Kampung Warna-Warni } \\
\hline No & Title & Link & Publisher & $\begin{array}{c}\text { Publish } \\
\text { Date }\end{array}$ \\
\hline \multirow{4}{*}{1} & Kampung Warna-warni Jodipan, \\
& Tempat Wisata Hits di Kota Malang & $\begin{array}{c}\text { https://travel.kompas.com/read/2 } \\
020 / 09 / 02 / 101000627 / \text { kampung- } \\
\text { warna-warni-jodipan-tempat- } \\
\text { wisata-hits-di-kota- } \\
\text { malang?page=all }\end{array}$ & Kompas & $\begin{array}{c}\text { Septembe } \\
\text { r } 2020\end{array}$ \\
\hline \multirow{2}{*}{2} & $\begin{array}{c}\text { Info Wisata Kampung Warna-warni } \\
\text { Jodipan: Rute, Harga Tiket, dan Tips }\end{array}$ & $\begin{array}{c}\text { https://www.idntimes.com/travel } \\
\text { /destination/naufal-al-rahman- } \\
\text { 1/info-wisata-kampung-warna- } \\
\text { warni-jodipan-rute-harga-tiket-dan- }\end{array}$ & IdnTimes & 16 Juni 20 \\
& & & \\
\hline
\end{tabular}




\begin{tabular}{|c|c|c|c|c|}
\hline & & tips & & \\
\hline 3 & $\begin{array}{c}\text { Kampung Warna-warni di Malang } \\
\text { Serasa di Luar Negeri }\end{array}$ & $\begin{array}{c}\text { https://travel.detik.com/dtravelers } \\
\text { _stories/u-4819392/kampung- } \\
\text { warna-warni-di-malang-serasa-di- } \\
\text { luar-negeri }\end{array}$ & Detik & $\begin{array}{l}12 \\
\text { Desembe } \\
\text { r } 2019\end{array}$ \\
\hline 4 & $\begin{array}{l}\text { Dibuka Kembali } 4 \text { September, } \\
\text { Kampung Warna-Warni Jodipan } \\
\text { Siapkan Protokol Kesehatan }\end{array}$ & $\begin{array}{c}\text { https:/ / travel.tribunnews.com/202 } \\
\text { 0/08/26/dibuka-kembali-4- } \\
\text { september-kampung-warna-warni- } \\
\text { jodipan-siapkan-protokol-kesehatan }\end{array}$ & Tribunnews & $\begin{array}{c}26 \\
\text { Agustus } \\
2020\end{array}$ \\
\hline 5 & $\begin{array}{c}\text { Mengintai Jodipan, Kampung } \\
\text { Warna-Warni di Malang Jawa } \\
\text { Timur }\end{array}$ & $\begin{array}{c}\text { https:// batampos.co.id/2019/06/3 } \\
\text { 0/mengintai-jodipan-kampung- } \\
\text { warna-warni-di-malang-jawa- } \\
\text { timur/ }\end{array}$ & Batampos & $\begin{array}{l}30 \text { Juni } \\
2019\end{array}$ \\
\hline 6 & $\begin{array}{l}\text { Kampung Warna-Warni: Usaha } \\
\text { Pemerintah Dalam Mendongkrak } \\
\text { Ekonomi Lokal }\end{array}$ & $\begin{array}{c}\text { https://wia.id/journal/kampung- } \\
\text { warna-warni-usaha-pemerintah- } \\
\text { dalam-mendongkrak-ekonomi- } \\
\text { lokal/ }\end{array}$ & Viva & $\begin{array}{c}18 \\
\text { Novembe } \\
\text { r } 2018\end{array}$ \\
\hline 7 & $\begin{array}{c}\text { Kampung Warna Jodipan: Dari } \\
\text { Dulu Hingga Sekarang }\end{array}$ & $\begin{array}{c}\text { https:/ / lontar.id/kampung-warna- } \\
\text { jodipan-dari-dulu-hingga- } \\
\text { sekarang/ }\end{array}$ & $\begin{array}{l}\text { Lontar } \\
\text { (media berita) }\end{array}$ & $\begin{array}{c}5 \\
\text { Agustus } \\
2019\end{array}$ \\
\hline 8 & $\begin{array}{c}15 \text { Tips Foto di Kota Lama Malang, } \\
\text { Kampung Warna Warni dan } \\
\text { Sekitarnya }\end{array}$ & $\begin{array}{l}\text { https:/ / dolandolen.com/15-tips- } \\
\text { foto-di-kota-lama-malang- } \\
\text { kampung-warna-warni-dan- } \\
\text { sekitarnya/ }\end{array}$ & $\begin{array}{c}\text { Dolan- } \\
\text { Dolen.com }\end{array}$ & $\begin{array}{c}15 \\
\text { Januari } \\
2018\end{array}$ \\
\hline 9 & $\begin{array}{c}\text { Kampung Warna Warni Jodipan } \\
\text { Malang }\end{array}$ & $\begin{array}{c}\text { https://indolora.co.id/artikel/kam } \\
\text { pung-warna-warni/ }\end{array}$ & $\begin{array}{l}\text { Indolora } \\
\text { (Agen } \\
\text { Penyewa } \\
\text { Mobil) }\end{array}$ & $\begin{array}{c}15 \\
\text { Oktober } \\
2019\end{array}$ \\
\hline 10 & $\begin{array}{l}\text { Kampung Warna-warni Malang, } \\
\text { Beneran Mirip di Brasil Lho }\end{array}$ & $\begin{array}{c}\text { https:/ / travelingyuk.com/kampun } \\
\text { g-warna-warni-jodipan- } \\
\text { malang/208757/ }\end{array}$ & Traveling Yuk & $\begin{array}{l}30 \text { Juni } \\
2019\end{array}$ \\
\hline 11 & $\begin{array}{c}\text { Kampung JODIPAN Malang Tiket } \\
\text { \& Daya Tarik - September } 2020\end{array}$ & $\begin{array}{c}\text { https://travelspromo.com/htm- } \\
\text { wisata/kampung-jodipan-malang/ }\end{array}$ & Travels promo & $\begin{array}{l}6 \text { April } \\
2020\end{array}$ \\
\hline 12 & $\begin{array}{l}\text { Sejarah dan Keindahan Kampung } \\
\text { Warna-Warni Jodipan Malang }\end{array}$ & $\begin{array}{c}\text { https://gotripina.com/blog/kamp } \\
\text { ung-warna-warni-jodipan-malang }\end{array}$ & - & $\begin{array}{c}27 \\
\text { Februari } \\
2020\end{array}$ \\
\hline 13 & $\begin{array}{l}\text { Visit Malang's Colorful Rainbow } \\
\text { Village: Kampung Warna Warni } \\
\text { Jodipan }\end{array}$ & $\begin{array}{c}\text { https://www.twowanderingsoles.c } \\
\text { om/blog/jodipan-malang- } \\
\text { kampung-warna-warni }\end{array}$ & - & $\begin{array}{c}19 \text { Maret } \\
2020\end{array}$ \\
\hline 14 & $\begin{array}{c}\text { Kampung Warna-Warni - The } \\
\text { Rebirth Of Jodipan And Tridi } \\
\text { Village }\end{array}$ & $\begin{array}{c}\text { https://claudiosieberphotography.c } \\
\text { om/countries/indonesia/malang- } \\
\text { jodipan-and-tridi-village/\#jp- }\end{array}$ & - & 2018 \\
\hline
\end{tabular}


The Role of City Design Elements in Tourist Villages as Interpreted by Online Media

Aurelia Silviana Theodora, Pamela Felita Julyanto, Adelia Tio Novita, Larasati Putri Kartika, Agus

Suharjono Ekomadyo, Vanessa Susanto.

\begin{tabular}{|c|c|c|c|c|}
\hline & & carousel-19751 & & \\
\hline 15 & $\begin{array}{c}\text { Kampung Wisata Jodipan, Bikin } \\
\text { Warga Hidup Mapan }\end{array}$ & $\begin{array}{c}\text { https://www.kompasiana.com/ha } \\
\text { nungprabowo/5acc80dfcbe5233a7b } \\
\text { 673202/kampung-wisata-jodipan- } \\
\text { bikin-warga-hidup-mapan }\end{array}$ & Kompasiana & $\begin{array}{l}24 \text { April } \\
2018\end{array}$ \\
\hline 16 & $\begin{array}{c}\text { Kampung Warna Warni Jodipan } \\
\text { Kembali Gelar Atraksi Wisata }\end{array}$ & $\begin{array}{c}\text { https://surabaya.bisnis.com/read/ } \\
\text { 20201004/531/1300475/kampung- } \\
\text { warna-warni-jodipan-kembali- } \\
\text { gelar-atraksi-wisata }\end{array}$ & Indana & $\begin{array}{c}4 \\
\text { Septembe } \\
\text { r } 2016\end{array}$ \\
\hline 17 & $\begin{array}{c}\text { "Kampung warna-warni" Malang, } \\
\text { dulu 'kumuh' sekarang jadi tempat } \\
\text { wisata }\end{array}$ & $\begin{array}{c}\text { https://www.bbc.com/indonesia/ } \\
\text { majalah/2016/10/161016_majalah_ } \\
\text { kampung_warna_warni_malang }\end{array}$ & BBC News & $\begin{array}{c}16 \\
\text { Oktober } \\
2016\end{array}$ \\
\hline 18 & $\begin{array}{l}\text { Hore! Kampung Warna Warni } \\
\text { Jodipan Malang akan dibuka } \\
\text { kembali pada tanggal ini }\end{array}$ & $\begin{array}{c}\text { https://lifestyle.kontan.co.id/news } \\
\text { /hore-kampung-warna-warni- } \\
\text { jodipan-malang-akan-dibuka- } \\
\text { kembali-pada-tanggal-ini }\end{array}$ & Kontari & $\begin{array}{l}24 \\
\text { Agustus } \\
2020\end{array}$ \\
\hline 19 & $\begin{array}{l}\text { Pesona Kampung Warna-Warni } \\
\text { Jodipan di Malang, Jawa Timur }\end{array}$ & $\begin{array}{c}\text { https://www.beritadaerah.co.id/20 } \\
\text { 20/09/11/pesona-kampung-warna- } \\
\text { warni-jodipan-di-malang-jawa- } \\
\text { timur/ }\end{array}$ & Berita daerah & $\begin{array}{c}11 \\
\text { Septembe } \\
\text { r } 2020\end{array}$ \\
\hline 20 & $\begin{array}{c}\text { Menelusuri Kampung Warna-warni } \\
\text { Jodipan dan Kampung Tridi (3D) }\end{array}$ & $\begin{array}{c}\text { https://www.andhirarum.com/201 } \\
\text { 9/02/ menelusuri-kampung-warna- } \\
\text { warni-jodipan.html }\end{array}$ & - & 2018 \\
\hline
\end{tabular}

\begin{tabular}{|c|c|c|c|c|}
\hline \multicolumn{5}{|c|}{ Kampung Pelangi } \\
\hline No & Title & Link & Publisher & $\begin{array}{l}\text { Publish } \\
\text { Date }\end{array}$ \\
\hline 1 & $\begin{array}{l}\text { Warna-Warni Kampung Pelangi } \\
\text { Semarang }\end{array}$ & $\begin{array}{c}\text { https://www.wego.co.id/berita/w } \\
\text { arna-warni-kampung-pelangi- } \\
\text { semarang/ }\end{array}$ & $\begin{array}{l}\text { Wego } \\
\text { Indonesia } \\
\text { Travel }\end{array}$ & 2019 \\
\hline 2 & $\begin{array}{c}\text { Kampung Pelangi Semarang, Wajah } \\
\text { Baru yang Mendunia }\end{array}$ & $\begin{array}{c}\text { https:// mytrip123.com/kampung- } \\
\text { pelangi-semarang/ }\end{array}$ & My Trip 123 & 2018 \\
\hline 3 & $\begin{array}{l}\text { Kampung Pelangi di Semarang, } \\
\text { Destinasi Wisata Saat Weekend }\end{array}$ & $\begin{array}{c}\text { https:// travel.detik.com/domestic- } \\
\text { destination/d-4919264/ kampung- } \\
\text { pelangi-di-semarang-destinasi- } \\
\text { wisata-saat-weekend }\end{array}$ & Detik Travel & $\begin{array}{c}29 \\
\text { Februari } \\
2020\end{array}$ \\
\hline 4 & $\begin{array}{l}\text { Puaskan Liburan di Semarang } \\
\text { Bareng Kampung Pelangi }\end{array}$ & $\begin{array}{c}\text { https://liupurnomo.com/kampung } \\
\text {-pelangi/ }\end{array}$ & - & $\begin{array}{l}23 \text { Maret } \\
2018\end{array}$ \\
\hline 5 & Kampung Pelangi Semarang: & https://wisataka.com/kampung- & Wisataka & 2018 \\
\hline
\end{tabular}




\begin{tabular}{|c|c|c|c|c|}
\hline & Sejarah, Tiket Masuk, Rute, Lengkap & pelangi-semarang/ & & \\
\hline 6 & $\begin{array}{c}\text { Kampung Pelangi Menjadi Wisata } \\
\text { Baru di Tengah Kota Semarang }\end{array}$ & $\begin{array}{c}\text { https://kumparan.com/masgala/k } \\
\text { ampung-pelangi-menjadi-wisata- } \\
\text { baru-di-tengah-kota-semarang }\end{array}$ & Kumparan & $\begin{array}{l}13 \text { Maret } \\
2018\end{array}$ \\
\hline 7 & $\begin{array}{c}12 \text { Potret Kampung Pelangi, Desa } \\
\text { Warna-Warni di Semarang yang } \\
\text { mendunia }\end{array}$ & $\begin{array}{l}\text { https://www.brilio.net/wow/12- } \\
\text { potret-kampung-pelangi-desa- } \\
\text { warna-warni-di-semarang-yang- } \\
\text { mendunia-170517u.html }\end{array}$ & Brilio & $\begin{array}{l}17 \text { Mei } \\
2017\end{array}$ \\
\hline 8 & $\begin{array}{l}\text { Kampung Pelangi Semarang, } \\
\text { Wilayah Kumuh yang Kini } \\
\text { Membuat Turis Terpesona }\end{array}$ & $\begin{array}{l}\text { https://artikel.rumah123.com/kam } \\
\text { pung-pelangi-semarang-wilayah- } \\
\text { kumuh-yang-kini-membuat-turis- } \\
\text { terpesona-65507 }\end{array}$ & rumah123 & $\begin{array}{l}13 \\
\text { Septemb } \\
\text { er } 2020\end{array}$ \\
\hline 9 & $\begin{array}{c}\text { Kampung Pelangi Semarang } \\
\text { Tempat Instagramable Untuk Anda } \\
\text { yang Suka Foto-foto }\end{array}$ & $\begin{array}{c}\text { https://www.reddoorz.com/blog/i } \\
\text { d/uncategorized/kampung- } \\
\text { pelangi-semarang }\end{array}$ & Red Doorz & $\begin{array}{l}5 \text { Januari } \\
2018\end{array}$ \\
\hline 10 & $\begin{array}{l}5 \text { Hal Menyenangkan di Kampung } \\
\text { Pelangi Semarang }\end{array}$ & $\begin{array}{c}\text { https://www.sintiaastarina.com/ka } \\
\text { mpung-pelangi-semarang/ }\end{array}$ & - & $\begin{array}{l}5 \text { Juni } \\
2019\end{array}$ \\
\hline 11 & $\begin{array}{l}\text { The Tiny Rainbow Village That's } \\
\text { Sparking an Instagram Craze }\end{array}$ & $\begin{array}{c}\text { https://www.vogue.com/article/ra } \\
\text { inbow-village-indonesia-instagram- } \\
\text { travel }\end{array}$ & Vogue & $\begin{array}{c}14 \text { Mei } \\
2017\end{array}$ \\
\hline 12 & $\begin{array}{c}\text { Dicat Kembali, Kampung Pelangi } \\
\text { Diharapkan Tarik Banyak } \\
\text { Wisatawan }\end{array}$ & $\begin{array}{l}\text { https://www.ayosemarang.com/re } \\
\text { ad/2019/11/10/47117/dicat- } \\
\text { kembali-kampung-pelangi- } \\
\text { diharapkan-tarik-banyak-wisatawan }\end{array}$ & Ayosemarang & $\begin{array}{l}10 \\
\text { Novemb } \\
\text { er } 2019\end{array}$ \\
\hline 13 & $\begin{array}{c}\text { Kampung Pelangi Semarang, } \\
\text { Menjadi Destinasi Wisata Nasional } \\
\text { dan Internasional }\end{array}$ & $\begin{array}{l}\text { https://www.intronesia.com/jawa } \\
\text { /jateng/kampung-pelangi- } \\
\text { semarang-menjadi-destinasi-wisata- } \\
\text { nasional-dan-internasional }\end{array}$ & intronesia & $\begin{array}{l}22 \\
\text { Februari } \\
2019\end{array}$ \\
\hline 14 & $\begin{array}{c}\text { Kampung Pelangi Semarang: Upaya } \\
\text { Membangkitkan Kemandirian } \\
\text { Warga }\end{array}$ & $\begin{array}{c}\text { https://www.timesindonesia.co.id/ } \\
\text { read/news/257498/kampung- } \\
\text { pelangi-semarang-upaya- } \\
\text { membangkitkan-kemandirian- } \\
\text { warga }\end{array}$ & $\begin{array}{l}\text { Time } \\
\text { Indonesia }\end{array}$ & $\begin{array}{l}18 \text { Maret } \\
2020\end{array}$ \\
\hline 15 & $\begin{array}{c}\text { Desa Pelangi, Ubah Wilayah Padat } \\
\text { dan Kumuh Jadi Tujuan Wisata }\end{array}$ & $\begin{array}{l}\text { https://www.kabarpenumpang.co } \\
\text { m/desa-pelangi-ubah-wilayah- } \\
\text { padat-dan-kumuh-jadi-tujuan- } \\
\text { wisata/ }\end{array}$ & $\begin{array}{l}\text { Kabarpenump } \\
\text { ang }\end{array}$ & $\begin{array}{l}6 \text { Juni } \\
2019\end{array}$ \\
\hline 16 & $\begin{array}{l}\text { Kampung Pelangi, Wisata Terbaru } \\
\text { Semarang Yang Mendunia! }\end{array}$ & $\begin{array}{c}\text { https:/ /liburmulu.com/kampung- } \\
\text { pelangi-semarang/ }\end{array}$ & liburmulu & $\begin{array}{l}20 \text { Juli } \\
2019\end{array}$ \\
\hline 17 & $\begin{array}{l}\text { Daya Tarik Serta Keindahan } \\
\text { Kampung Pelangi Semarang }\end{array}$ & $\begin{array}{c}\text { https://sukanyasar.com/tempat/k } \\
\text { ampung-pelangi/ }\end{array}$ & sukanyasar & 2018 \\
\hline
\end{tabular}


The Role of City Design Elements in Tourist Villages as Interpreted by Online Media

Aurelia Silviana Theodora, Pamela Felita Julyanto, Adelia Tio Novita, Larasati Putri Kartika, Agus

Suharjono Ekomadyo, Vanessa Susanto.

\begin{tabular}{|c|c|c|c|c|}
18 & $\begin{array}{c}\text { Kampung Pelangi Semarang Tiket \& } \\
\text { Keindahan -September 2020 }\end{array}$ & $\begin{array}{c}\text { https://travelspromo.com/htm- } \\
\text { wisata/kampung-pelangi- } \\
\text { semarang/ }\end{array}$ & Travelspromo & $\begin{array}{c}11 \text { Maret } \\
2020\end{array}$ \\
\hline 19 & $\begin{array}{c}\text { Puaskan Liburan di Semarang } \\
\text { Bareng Kampung Pelangi }\end{array}$ & $\begin{array}{c}\text { https://liupurnomo.com/kampung } \\
\text {-pelangi/ }\end{array}$ & - & $\begin{array}{c}23 \text { Maret } \\
2018\end{array}$ \\
\hline \multirow{2}{*}{20} & $\begin{array}{c}\text { Dari Kampung Pelangi Pinggir Kali, } \\
\text { Kamus Wisata Semarang Bertambah } \\
\text { Lagi }\end{array}$ & $\begin{array}{c}\text { https://www.tutyqueen.com/2018 } \\
/ \text { O2/kampung-pelangi- } \\
\text { semarang.html }\end{array}$ & - & 2018 \\
\hline
\end{tabular}

